\begin{tabular}{|c|c|c|}
\hline & \multicolumn{2}{|c|}{ Cell Physiol Biochem 2018;46:2239-2249 } \\
\hline & $\begin{array}{l}\text { DOI: 10.1159/000489592 } \\
\text { Published onIIne: Mray 07, } 2018\end{array}$ & $\begin{array}{l}\text { (c) } 2018 \text { The Author(s) } \\
\text { Published by S. Karger AG, Basel } \\
\text { www.karger.com/cpb }\end{array}$ \\
\hline & Accepted: March 05, 2018 & \\
\hline $\begin{array}{l}\text { Cellular Physiology } \\
\text { and Biochemistry }\end{array}$ & $\begin{array}{l}\text { This article is licensed under the } C \\
\text { tional License (CC BY-NC-ND) (htth } \\
\text { for commercial purposes as well as }\end{array}$ & $\begin{array}{l}\text { NonCommercial-NoDerivatives } 4.0 \text { Inter } \\
\text { DpenAccessLicense). Usage and distribut } \\
\text { naterial requires written permission. }\end{array}$ \\
\hline
\end{tabular}

\title{
Association of MiRNA-146a, MiRNA-499, IRAK1 and PADI4 Polymorphisms with Rheumatoid Arthritis in Egyptian Population
}

\author{
Olfat Gamil Shaker ${ }^{\mathrm{N}} \quad$ Noha Ahmed EL Boghdady ${ }^{\mathrm{b}} \quad$ Abeer El-Dessouki El Sayed ${ }^{c}$ \\ aMedical Biochemistry and Molecular Biology Department, Faculty of Medicine, Cairo University, Cairo, \\ 'biochemistry Department, Faculty of Pharmacy, Cairo University, Cairo, 'Police hospital, New Cairo, \\ Cairo, Egypt
}

\section{Key Words}

Rheumatoid arthritis • MiRNA-146a • MiRNA-499 • IRAK1 • PADI4

\begin{abstract}
Background/Aims: Rheumatoid arthritis (RA) is a systemic autoimmune disease affecting up to $1 \%$ of the population worldwide. The aim of the present study was to investigate whether miRNA-146a rs2910164, miRNA-499 rs3746444, IRAK1 rs3027898 and PADI4 rs1748033 polymorphisms are associated with susceptibility to RA in Egyptians and whether they influence disease severity and activity. Methods: The study was performed on 104 unrelated RA patients and 112 healthy subjects. RA patients were further subdivided into active and inactive RA groups. Polymorphisms were genotyped by using real-time polymerase chain reaction with TaqMan allelic discrimination assay. Results: Significant differences in the frequency of miRNA-146a rs2910164, miRNA-499 rs3746444, IRAK1 rs3027898 and PADI4 rs1748033 alleles and genotypes were observed between RA patients and controls. Only CA and AA genotypes of IRAK1 rs3027898 shows a significant difference between active and inactive subgroups. MiRNA-146a rs2910164 and IRAK1 rs3027898 polymorphisms were a risk factor for predisposition to RA in codominant and dominant tested inheritance models, while, the miRNA-499 rs3746444 and PADI4 rs1748033 polymorphisms were a risk factor in codominant and recessive one. CG and GG genotypes of miRNA-146a rs2910164 were associated with positive erosions. CA genotype of IRAK1 rs3027898 was associated with low disease activity and negative erosions, while, the AA genotype was associated with high disease activity. CC genotype of PADI4 rs1748033 was associated with negative rheumatoid factor. Conclusion: The 4 studied SNPs were likely to play an important role in the susceptibility to RA and can influence disease severity and activity in Egyptian population.
\end{abstract}




\section{Introduction}

Rheumatoid arthritis (RA) is a persistent joint inflammatory disease which can appear in people of any age. The prevalence of RA increases with age affecting approximately $6 \%$ of the population over age of 65 [1]. As in other autoimmune diseases (ADs), females are affected more often than males [2]. Both ecological and heredity factors have been involved in RA susceptibility. The principle heredity factor for RA is the HLA-DRB1 gene, however, the HLA genes deem a 33\% of the heredity liability to disease [3]. Latterly, many non-HLA genes have been identified to be associated with RA susceptibility [4]. One class of heredity variants that has been the focus of attention recently is the class of DNA polymorphisms that affect microRNA (miRNA) binding to their target messenger RNA (mRNA), leading to translational repression or mRNA degradation $[5,6]$.

MiRNAs form a class of noncoding RNAs that are assumed to be diagnostic and prognostic biomarkers of several diseases [7]. They are present in many biological fluids, involving saliva, semen, vaginal secretions and menstrual blood [8].They are contributed in the organization of most biologic processes as chromosome architecture, cell proliferation, apoptosis, stress resistance, and stem cell maintenance [9, 10]. Many studies have announced that polymorphisms in miRNA and its target sites influence the pathogenesis of several human diseases, including RA $[11,12]$. MiRNA-146a could control the expression of interleukin (IL)-1 receptor-associated kinase (IRAK1), IRAK2 and targets tumor necrosis factor (TNF) receptor-associated factor 6 (TRAF6), which are regulators of the TNF- $\alpha$ signaling pathway [13]. Increased expression level of miRNA-146a was detected in the synovial fluid and peripheral blood mononuclear cells of RA patients than disease control and healthy subjects. Its expression level is positively correlated with levels of TNF- $\alpha$ and with RA disease activity $[5,14]$. On the other hand, miRNA-499 targets IL-17 receptor B (IL-17RB), IL-23a, IL-2R $\beta$, IL-6, IL-2, IL-18R, IL-21 and peptidyl arginine deiminase type 4 (PADI4). All of these inflammatory cytokines play an important role in the pathogenesis of RA [15-17].

Therefore, miRNA-146a and miRNA-499 and their genes targets represent a new group of molecules, which seem to be very promising in the discovery of new heredity variants that could predispose to RA susceptibility. The aim of the present study is to investigate the role of certain polymorphisms in miRNA-146a rs2910164 gene, and its target IRAK1 rs3027898 gene, as well as in miRNA-499 rs3746444 gene and its target PADI4 rs1748033 gene in RA susceptibility in a sample of Egyptian people and to examine whether these polymorphisms can influence the severity and activity of the disease.

\section{Materials and Methods}

\section{Subjects}

One hundred and four unrelated RA patients (88 females and 16 males, mean age 39.5 10.75 years) were enrolled in the study and diagnosed according to the 1987 American College of Rheumatology criteria for RA [18]. They were recruited from cases admitted and followed up in Rheumatology unit, Kasr Al-Ainy Hospital, Faculty of Medicine, Cairo University, during the period from October 2015 to October 2016. Their ages and general characteristics are summarized in Table 1.

All patients underwent complete history taking especially for disease duration and presenting symptoms or joint affection. Complete blood picture (CBC), alanine aminotransferase (ALT) and creatinine were measured to exclude any patients suffering from kidney or liver diseases. Disease activity was assessed by measuring the erythrocyte sedimentation rate (ESR), anti nuclear antibody (ANA) and 28-joint disease activity score (DAS28). RA patients were splited into two subgroups as indicated by their DAS28 into 48 (46\%) patients with score $>3.2$ and they were considered as active RA patients, while 56 (54\%) with score $\leq 3.2$ were considered inactive RA patients. Disease severity was assessed by number of patients with erosions and seropositivity for rheumatoid factor (RF). 24 (23\%) patients have positive erosions, while 76 (73\%) have positive RF. Plain X-ray films (postero-anterior and oblique views) of the hands/wrist of patients were obtained. 
In addition, 112 age and sex matched healthy volunteers were enrolled in the study and were considered as normal control group. They were recruited from healthy subjects admitted to the same hospital for routine checkup. They did not suffer hypertension, liver or renal diseases and no known past or family history of RA. Controls were 86 females and 26 males with a mean age of $(41 \pm 11.13)$ years. A written informed consent was obtained from all subjects prior to their inclusion in the study. The research protocol was affirmed by the Ethics Committees of Faculty of Pharmacy, Cairo University.

\section{Sample collection and biochemical tests}

Venous blood samples $(5 \mathrm{ml})$ were collected and CBC as well as ESR were performed. A portion of blood was admitted to clot and centrifuged at $4^{\circ} \mathrm{C}$ to separate serum used for assessment of ALT, creatinine, ANA and RF. ALT and creatinine assays were performed using standard diagnostic kits supplied by (Quimica Clinica Aplicada, Spain). ANA and RF were assessed by immunofluoresence technique, following the manufacturer's instructions. A second portion of blood was assembled in vacutainer tubes containing EDTA and was stored at $-80^{\circ} \mathrm{C}$ until DNA extraction.

\section{DNA extraction and genotyping assay:}

DNA was extracted from entire blood utilizing QIA-amplification extraction kit (Qiagen, Venlo, Limburg, Netherlands). DNA samples were quantitated utilizing the NanoDrop1-1000 spectrophotometer (NanoDrop innovations, Inc., Wilmington, USA). Genotyping was performed using real-time polymerase chain reaction with TaqMan allelic discrimination assay (Applied Biosystems, USA). Single nucleotide polymorphisms (SNPs) of miRNA-146a rs2910164, IRAK1 rs3027898, miRNA-499 rs3746444 and PADI4 rs1748033 were analyzed in the extracted DNA by using specific primers and Taqman probes (Taqman genotyping assays, Applied Biosystems, USA). The following PCR primers were used for miRNA-146a rs2910164: 5'CATGGGTTGTGTCAGTGTCAGACCT 3'(forward) and 5'TGAAATTCAGTTCTTCAGCTGGGAT3'(r everse); for miRNA-499 rs3746444: 5'ATGTTTAACTCCTCTCCACGTGAAC3'(forward) and 5'TCACAGCAAGT CTGTGCTGCTTCCC3'(reverse); for IRAK1 rs3027898: 5'ACAAGACCCTGGACGCTCAAGAACC3'(forward) and 5'TGAAGTGTAAGGCATCAGGAAAGCT3'(reverse); for PADI4 rs1748033: 5'ACTTGATGGGATTTCAGAAATCTC C3'(forward) and 5'TGTGCGCAGACATCACCCGCACCGG 3'(reverse). Probes were synthesized with reporter dye FAM or VIC covalently linked at the 5' end and a quencher dye MGB linked to the 3' end of the probe (Applied Biosystems, USA). Extracted genomic DNA was amplified in a $50 \mu \mathrm{l}$ solution. After a denaturation time of $10 \mathrm{~min}$ at $95^{\circ} \mathrm{C}, 45$ cycles at $92^{\circ} \mathrm{C}$ for $15 \mathrm{~s}$ then $60^{\circ} \mathrm{C}$ for $90 \mathrm{~s}$ for annealing and extension were carried out and fluorescence was measured at the end of every cycle and the endpoint. PCR products were checked by a Rotor gene Q Real Time PCR System (Qiagen, Valencia, CA, and USA) (Fig. 1). Homology searches using BLAST was carried out to confirm the nucleotide sequence [19].

\section{Statistical analysis}

Statistical Package for the Social Science (IBM SPSS) version 22 was used for statistical calculations. Results were expressed as mean \pm standard deviation $(\mathrm{M} \pm \mathrm{SD}$ ) or frequencies (number of cases) and percentages when appropriate. Association of different genotypes with Hardy-Weinberg equilibrium (HWE), the genotypes distribution and allele's frequencies of each SNP in RA patients and controls, or

Table 1. General characteristic of RA patients. Quantitative data were presented as $\mathrm{M} \pm \mathrm{SD}$; qualitative data were presented as number and percent $\mathrm{n}(\%)$. CBC: complete blood picture; Hb: Hemoglobin; TLC: total leucocytes count; PLC: platelet count; ALT: alanine aminotransferase; Cr: creatinine; ESR: erythroDAS28:28-joint disease activity score; RF: rheumatoid factor

\begin{tabular}{|c|c|}
\hline Variable & RA Patients \\
\hline $\mathrm{n}$ & 104 \\
\hline Age, years & $39.5 \pm 10.75$ \\
\hline \multicolumn{2}{|l|}{ Sex } \\
\hline Male & $16(15.38)$ \\
\hline Female & $88(84.61)$ \\
\hline Disease duration, years & $7 \pm 5.04$ \\
\hline \multicolumn{2}{|l|}{$\mathrm{CBC}$} \\
\hline $\mathrm{Hb}(\mathrm{gm} / \mathrm{dl})$ & $11.71 \pm 1.54$ \\
\hline TLCx $\left(10^{9}\right.$ cell/liter $)$ & $7.67 \pm 2.34$ \\
\hline PLC ( x1090alatlet/liter $)$ & $322 \pm 200.34$ \\
\hline $\operatorname{ALT}(U / L)$ & $29.77 \pm 22.88$ \\
\hline $\mathrm{Cr}(\mathrm{mg} / \mathrm{dl})$ & $0.93 \pm 0.81$ \\
\hline \multicolumn{2}{|l|}{ Disease activity } \\
\hline$-\operatorname{ESR}(\mathrm{mm} / \mathrm{hr})$ & $41.79 \pm 23.67$ \\
\hline \multicolumn{2}{|l|}{ - ANA } \\
\hline $\mathrm{ANA}^{+}$ & $14(13.5)$ \\
\hline ANA $^{-}$ & $84(80.8)$ \\
\hline \multicolumn{2}{|l|}{-DAS 28} \\
\hline Low disease activity $(\leq 3.2)$ & $56(54)$ \\
\hline Moderate to high disease activity $(>3.2)$ & $48(46)$ \\
\hline \multicolumn{2}{|l|}{ Disease severity } \\
\hline \multicolumn{2}{|l|}{-Erosions } \\
\hline Erosions $^{+}$ & $24(23)$ \\
\hline Erosions- & $80(77)$ \\
\hline \multicolumn{2}{|l|}{$-R F$} \\
\hline $\mathrm{RF}^{+}$ & $76(73)$ \\
\hline $\mathrm{RF}^{-}$ & $28(27)$ \\
\hline
\end{tabular}




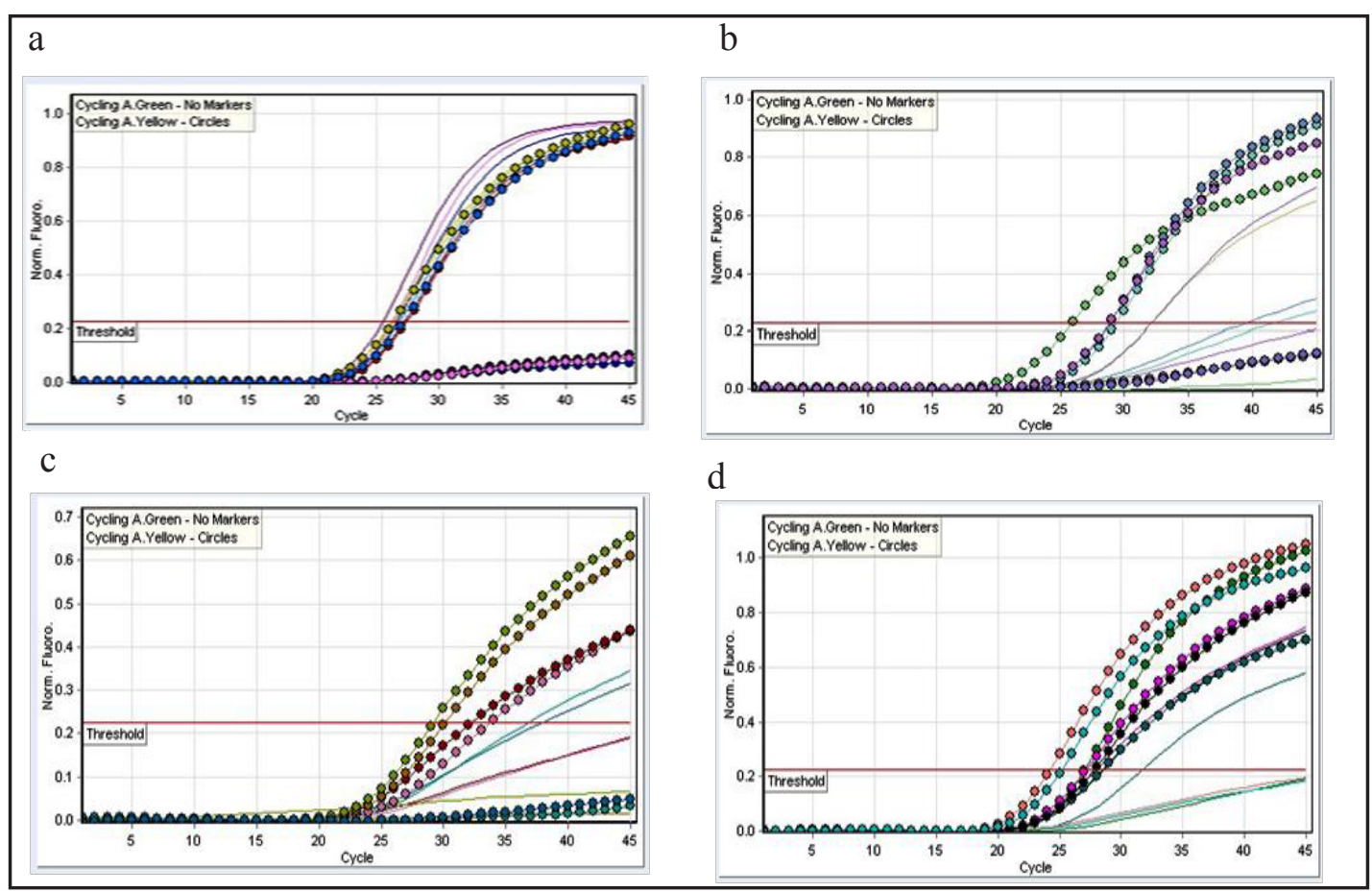

Fig. 1. Genotyping of (a) miRNA-146a (C/G) rs2910164, (b) IRAK1 (C/A) rs3027898, (c) miRNA-499 (T/C) rs3746444 and (d) PADI4 (T/C) rs1748033 by real-time PCR. Representative allelic discrimination for cycling A. Green FAM- No Markers (G allele for miRNA-146a, A allele for IRAK1, and C allele for miRNA-499 and PADI4 homozygous recessive) and cycling A. Yellow VIC-Circles (C allele for miRNA-146a and IRAK1, and T allele for miRNA-499 and PADI4 homozygous dominant).

in active RA and inactive RA patient groups were analyzed using the Chi-square test. Kruskal Wallis test with Mann Whitney as post-hoc pairwise comparisons were used to compare numerical variables between groups. Multivariate logistic regression analysis models, odds ratios (ORs) and 95\% confidence intervals (CIs) of crude ORs and of age and sex adjusted ORs were used to test for the preferential effect of each gene mutation on the occurrence of cases. P values less than 0.05 was considered statistically significant.

\section{Results}

The observed genotype frequencies for the polymorphism in RA patients and control subjects were in HWE for miRNA-146a ( $\mathrm{P}=0.42$ and 0.12 , respectively) and miRNA-499 $(\mathrm{P}=0.25$ and 0.8 , respectively), while did not conform to HWE for IRAK1 ( $\mathrm{P}=0.04$ and 0.001 , respectively) and PADI4 ( $\mathrm{P}=0.001$ and 0.001 , respectively).

The genotype distributions of the four studied SNPs in all subjects are illustrated in Table 2. MiRNA-146a rs2910164 showed a highly statistically significant difference in the $\mathrm{G}$ allele frequency $(\mathrm{P}=0.001)$ and $\mathrm{GG}$ genotype distribution $(\mathrm{P}=0.03)$. The $\mathrm{G}$ allele and the homozygote genotype GG were more frequent in RA patients than controls (48\% vs $32.1 \%$, respectively, for the G allele and $21.2 \%$ vs $7.14 \%$, respectively, for the GG genotype). IRAK1 rs3027898 revealed a statistically significant difference in the A allele frequency $(\mathrm{P}=0.01)$ and CA genotype distribution $(\mathrm{P}=0.001)$. Where, the A allele and the heterozygous genotype CA were more frequent in the RA patients than controls ( $40.38 \%$ vs $29.46 \%$, respectively, for the $\mathrm{A}$ allele and $38.46 \%$ vs $8.9 \%$, respectively, for the CA genotype). In the codominant and dominant models when CC homozygote genotype of miRNA-146a and of IRAK1 were used as reference group, the CG, GG and CG+GG genotypes of miRNA-146a and the CA, AA and CA+AA genotypes of IRAK1 were associated with a significant increased risk of RA. Beside, miRNA-499 rs3746444 and PADI4 rs1748033 exhibited a highly statistically significant difference in 
Shaker et al.: MiRNA-146a, miRNA-499, IRAK1 and PADI4 Polymorphisms In Rheumatoid Arthritis

the $\mathrm{C}$ allele frequency $(\mathrm{P}=0.003$ and 0.002 , respectively) and in the CC genotype distribution $(\mathrm{P}=0.003$ and 0.05 , respectively). For miRNA-499, the $\mathrm{C}$ allele and the homozygote genotype CC were more frequent in the RA patients than controls $(52.89 \%$ vs $38.39 \%$, respectively, for the $\mathrm{C}$ allele and $30.8 \%$ vs $14.3 \%$, respectively, for the CC genotype). For PADI4, the $\mathrm{C}$ allele and the homozygote genotype CC were more frequent in the RA patients than controls ( $31.73 \%$ vs $29.58 \%$, respectively, for the $\mathrm{C}$ allele and $30.77 \%$ vs $16.07 \%$ respectively for the CC genotype). In the codominant and recessive models when TT or TT+TC genotypes of miRNA-499 and of PADI4 were used as reference group, only the CC genotype of miRNA-499 and PADI4 were associated with a significant increased risk of RA

Table 3 compared the genotype distributions of the four studied SNPs in active to inactive RA patients. There was no significant difference in the distribution of genotypes and the allelic frequency of miRNA146a rs2910164, miRNA-499 rs3746444, and PADI4 rs1748033, neither in the allelic frequency of IRAK1 rs3027898. However, IRAK1 rs3027898 genotypes distribution reported a significant difference between the two groups $(\mathrm{P}=0.025)$. The heterozygote $\mathrm{CA}$ genotype was more frequent in the inactive RA in comparison to the active RA ( $50 \%$ vs $25 \%$, respectively), while the homozygous AA genotype was more frequent in the active RA relative to the inactive RA ( $29.16 \%$ vs $14.3 \%$, respectively). But this significant difference in genotypes was disappeared when adjusting the age and sex of patients.

As IRAK1 gene is coded on the $\mathrm{x}$ chromosome, we evaluate the effect of IRAK1 rs3027898 genotypes on RA risk according to different gender (Table 4). A significant increased risk of
Table 2. Logistic regression analysis of associations between miRNA-146a rs2910164 C/G, IRAK1 rs3027898 C/A, miRNA-499 rs3746444 T/C and PADI4 rs1748033 T/C gene polymorphisms with RA risk in controls and RA patients. Data are reported as number and percent $\mathrm{n}(\%)$. rs: reference singlenucleotide polymorphism (SNP) ID; OR: odds ratio; CI: confidence interval. Adjusted OR is data adjusted for age and sex. $P$ values less than 0.05 are statistically significant

\begin{tabular}{|c|c|c|c|c|c|c|c|}
\hline & & $\begin{array}{l}\text { Controls } \\
(\mathrm{n}=112) \\
\end{array}$ & $\begin{array}{l}\text { RA Patients } \\
(\mathrm{n}=104)\end{array}$ & OR $(95 \% \mathrm{CI})$ & $P$ value & $\begin{array}{c}\text { Adjusted } \\
\text { OR (95\% CI) }\end{array}$ & $P$ value \\
\hline \multicolumn{8}{|c|}{ miRNA-146a rs2910164 C/G } \\
\hline \multirow[t]{3}{*}{ Codominant } & $\mathrm{CC}$ & $48(42.9)$ & $26(25)$ & 1.00 & Reference & 1.00 & Reference \\
\hline & CG & $56(50)$ & $56(53.8)$ & $2.48(1.24-4.95)$ & 0.01 & $1.99(1.26-3.14)$ & 0.003 \\
\hline & GG & $8(7.14)$ & $22(21.2)$ & $3.2(1.1-9.2)$ & 0.03 & & \\
\hline Dominant & $\mathrm{CG}+\mathrm{GG}$ & $64(57.14)$ & $78(75)$ & $2.3(1.27-4.19)$ & 0.006 & $2.32(1.27-4.27)$ & 0.007 \\
\hline \multirow{2}{*}{ Recessive } & $\mathrm{CC}+\mathrm{CG}$ & $104(92.9)$ & $82(78.8)$ & 1.00 & Reference & 1.00 & Reference \\
\hline & GG & $8(7.1)$ & $22(21.2)$ & $2.42(0.9-6.1)$ & & $2.36(0.93-5.98)$ & 0.071 \\
\hline \multirow{2}{*}{ Alleles } & C & $152(67.9)$ & $108(51.9)$ & & Reference & & \\
\hline & \multicolumn{7}{|c|}{ IRAK1 rs3027898 C/A } \\
\hline \multirow[t]{3}{*}{ Codominant } & CC & $74(66.07)$ & $42(40.38)$ & 1.00 & Reference & 1.00 & Reference \\
\hline & $\mathrm{CA}$ & $10(8.9)$ & $40(38.46)$ & $0.14(0.06-0.31)$ & 0.001 & $0.73(0.51-1.03)$ & 0.07 \\
\hline & $\mathrm{AA}$ & $28(25)$ & $22(21.53)$ & $5.95(2.26-15.7)$ & 0.0003 & & \\
\hline Dominant & $\mathrm{CA}+\mathrm{AA}$ & $38(33.9)$ & $62(59.62)$ & $0.35(0.2-0.6)$ & 0.0002 & $1.36(0.69-2.65)$ & 0.37 \\
\hline \multirow{2}{*}{ Recessive } & $\mathrm{CC}+\mathrm{CA}$ & $84(75)$ & $82(78.84)$ & 1.00 & Reference & & Reference \\
\hline & $\mathrm{AA}$ & $28(25)$ & $22(21.53)$ & $1.24(0.66-2.35)$ & 0.5 & $0.31(0.17-0.57)$ & 0.000 \\
\hline \multirow[t]{2}{*}{ Alleles } & $\mathrm{c}$ & $158(70.53)$ & $124(59.6)$ & & Reference & & \\
\hline & A & $66(29.46)$ & $84(40.38)$ & & 0.01 & & \\
\hline \multicolumn{8}{|c|}{ miRNA- $499 \mathrm{rs} 3746444 \mathrm{~T} / \mathrm{C}$} \\
\hline \multirow[t]{3}{*}{ Codominant } & TT & $42(37.5)$ & $26(25)$ & 1.00 & Reference & 1.00 & Reference \\
\hline & TC & $54(48,2)$ & $46(44.2)$ & $1.38(0.73-2.58)$ & 0.318 & $1.61(1.07-2.42)$ & 0.02 \\
\hline & $\mathrm{CC}$ & $16(14.3)$ & $32(30.8)$ & $3.23(1.49-7)$ & 0.003 & & \\
\hline Dominant & $\mathrm{TC}+\mathrm{CC}$ & $70(62.5)$ & $78(75)$ & $1.62(0.88-2.9)$ & 0.119 & $1.57(0.84-2.93)$ & 0.15 \\
\hline \multirow[t]{2}{*}{ Recessive } & $\mathrm{TT}+\mathrm{TC}$ & $96(85.71)$ & $72(69.2)$ & 1.00 & Reference & 1.00 & Reference \\
\hline & CC & $16(14.28)$ & $32(30.8)$ & $2.67(1.36-5.23)$ & 0.0043 & $2.58(1.23-5.44)$ & 0.012 \\
\hline \multirow{2}{*}{ Alleles } & $\mathrm{T}$ & $138(61.6)$ & $98(47.12)$ & & Reference & & \\
\hline & c & $86(38.39)$ & $110(52.89)$ & & 0.003 & & \\
\hline \multicolumn{8}{|c|}{ PADI4 rs1748033 T/C } \\
\hline \multirow[t]{3}{*}{ Codominant } & TT & $88(78.6)$ & $70(67.3)$ & 1.00 & Reference & 1.00 & Reference \\
\hline & TC & $6(5.3)$ & & $2.38(0.47-2.18)$ & & $0.72(0.51-1.01)$ & 0.06 \\
\hline & $\mathrm{CC}$ & $18(16.07)$ & $32(30.77)$ & $0.19(0.03-1.03)$ & 0.05 & & \\
\hline & $\mathrm{TC}+\mathrm{CC}$ & $24(21.43)$ & $34(32.7)$ & $0.56(0.31-1.03)$ & 0.06 & $0.43(0.22-0.85)$ & 0.016 \\
\hline \multirow{2}{*}{ Recessive } & $\mathrm{TT}+\mathrm{TC}$ & $94(83.92)$ & $72(69.23)$ & 1.00 & Reference & & Reference \\
\hline & $\mathrm{cc}$ & $18(16.07)$ & $32(30.8)$ & $0.43(0.22-0.82)$ & 0.01 & $0.51(0.26-1.03)$ & 0.05 \\
\hline \multirow[t]{2}{*}{ Alleles } & T & $182(81.25)$ & $142(68.27)$ & & Reference & & \\
\hline & $\mathrm{C}$ & $42(29.58)$ & $66(31.73)$ & & 0.002 & & \\
\hline
\end{tabular}

Table 3. Logistic regression analysis of associations between miRNA-146a rs2910164 C/G, IRAK1 rs3027898 C/A, miRNA-499 rs3746444 T/C and PADI4 rs1748033 T/C gene polymorphisms with RA risk in active and inactive RA patients. Data are reported as number and percent n (\%). rs: reference single-nucleotide polymorphism (SNP) ID. Adjusted OR is data adjusted for age and sex. P values less than 0.05 are statistically significant

\begin{tabular}{|c|c|c|c|c|c|c|}
\hline & & Active RA $(\mathrm{n}=48)$ & Inactive $\mathrm{RA}(\mathrm{n}=56)$ & $P$ value & Adjusted OR $(95 \% \mathrm{CI})$ & Pvalue \\
\hline \multicolumn{7}{|c|}{ miRNA-146ars2910164 C/G } \\
\hline \multirow[t]{2}{*}{ Genotypes } & CC & $10(20.8)$ & $16(28.5)$ & & \multirow{5}{*}{$1.18(0.66-2.09)$} & \multirow{5}{*}{0.58} \\
\hline & CG & $28(58.33)$ & $28(50)$ & 0.62 & & \\
\hline \multirow{3}{*}{ Alleles } & GG & $10(20.8)$ & $12(21.46)$ & \multirow{3}{*}{0.6} & & \\
\hline & $\mathrm{C}$ & $48(50)$ & $60(53.57)$ & & & \\
\hline & G & $48(50)$ & $52(46.4)$ & & & \\
\hline \multicolumn{7}{|c|}{ IRAK1 rs3027898 C/A } \\
\hline \multirow[t]{2}{*}{ Genotypes } & CC & $22(45.83)$ & $20(35.7)$ & & \multirow{5}{*}{$0.94(0.56-1.57)$} & \multirow{5}{*}{0.79} \\
\hline & $\mathrm{CA}$ & $12(25)$ & $28(50)$ & 0.025 & & \\
\hline & $\mathrm{AA}$ & $14(29.16)$ & $8(14.3)$ & \multirow{3}{*}{0.72} & & \\
\hline \multirow[t]{2}{*}{ Alleles } & $\mathrm{C}$ & $56(58.3)$ & $68(60.7)$ & & & \\
\hline & A & $40(41.7)$ & $44(39.3)$ & & & \\
\hline \multicolumn{7}{|c|}{ miRNA $499 \mathrm{rs} 3746444 \mathrm{~T} / \mathrm{C}$} \\
\hline \multirow[t]{2}{*}{ Genotypes } & TT & $12(25)$ & $14(25)$ & & \multirow{5}{*}{$1.04(0.61-1.77)$} & \multirow{5}{*}{0.884} \\
\hline & $\mathrm{TC}$ & $20(41.6)$ & $26(46.4)$ & 0.86 & & \\
\hline \multirow{3}{*}{ Alleles } & $\mathrm{CC}$ & $16(33.3)$ & $16(28.5)$ & \multirow{3}{*}{0.73} & & \\
\hline & $\mathrm{T}$ & $44(45.8)$ & $54(48.2)$ & & & \\
\hline & $\mathrm{C}$ & $52(54.2)$ & $58(51.8)$ & & & \\
\hline \multicolumn{7}{|c|}{ PADI4 rs1748033 T/C } \\
\hline \multirow[t]{3}{*}{ Genotypes } & TT & $30(62.5)$ & $40(71.42)$ & & \multirow{5}{*}{$0.79(0.52-1.2)$} & \multirow{5}{*}{0.275} \\
\hline & TC & 0 & $2(3.57)$ & 0.18 & & \\
\hline & $\mathrm{CC}$ & $18(37.5)$ & $14(25)$ & & & \\
\hline \multirow[t]{2}{*}{ Alleles } & $\mathrm{T}$ & $60(62.5)$ & $82(73.2)$ & \multirow[t]{2}{*}{0.09} & & \\
\hline & $\mathrm{C}$ & $36(37.5)$ & $30(26.8)$ & & & \\
\hline
\end{tabular}


Shaker et al.: MiRNA-146a, miRNA-499, IRAK1 and PADI4 Polymorphisms In Rheumatoid Arthritis

RA associated with the IRAK1 rs3027898 CA genotype $(\mathrm{P}=0.00)$ and $\mathrm{A}$ allele $(\mathrm{P}=0.00)$ were more evident among females compared to males.

Assessment of the 4 SNPs genotypes associations with the disease severity and activity parameters in RA patients were established in Table 5. Significant association was observed between miRNA146a rs2910164 and IRAK1 rs3027898 polymorphisms with one of the disease severity parameters, erosions, $(\mathrm{P}=0.05$ and 0.009 , respectively). The percent of patients having positive erosions were significantly increased among patients carrying CG or GG genotypes in miRNA-146a, while significantly decreased among patients carrying CA genotype in IRAK1when compared to CC genotype. In addition, IRAK1 showed a significant association with one of the activity parameters, DAS28, where the percent of patients having moderate to high disease activity were significantly decreased among patients carrying CA compared to CC genotypes and increased among patients carrying AA compared to CA genotypes ( $\mathrm{P}=0.02)$. MiRNA-499 rs3746444 and PADI4 rs1748033 showed a significant association with one of the activity parameters, positive ANA, ( $\mathrm{P}=0.002$ and 0.001 , respectively). Positive ANA were significantly increased among patients carrying TT or TC genotypes compared to CC genotype of miRNA-499 and among patients carrying TC or CC genotypes compared to TT genotype of PADI4. Additionally, PADI4 shows significant association with ESR levels $(\mathrm{P}=0.05)$, where ESR values were significantly elevated among patients carrying TT and CC genotypes when compared to TC genotypes. Beside, PADI4 shows a significant association with two of the severity parameters positive erosions and $\mathrm{RF}(\mathrm{P}=0.02$, each one).Where positive erosions were significantly increased in TC genotype and positive RF were significantly decreased among CC genotype compared to TT genotype.

\section{Discussion}

Genetic polymorphisms of miRNA-146a rs2910164, miRNA-499 rs3746444, IRAK1 rs3027898 and PADI4 rs1748033 were analyzed with susceptibility of RA in a sample of Egyptian population. A significant difference was noticed in the distribution of the 4 studied SNPs genotypes and their minor alleles between RA patients and controls. The prevalence of miRNA-146a rs2910164 GG genotype and G allele, IRAK1 rs3027898 CA genotype and A allele, miRNA-499 rs3746444 and PADI4 rs1748033 CC genotype and their C alleles were identified as significantly higher in RA patients. By comparing the active and inactive RA groups only the CA and AA genotypes of IRAK1 rs3027898 showed a significant difference. Where, the rs3027898 CA genotype was more frequent in inactive RA and the rs3027898 AA genotype was more frequent in active RA group. No significant difference was observed in the distribution of miRNA-499 rs3746444 genotypes with the disease severity and activity parameters in RA patients, while, the CG and GG genotypes of miRNA-146a were associated with positive erosions. IRAK1 CA genotype was associated with low disease activity and negative erosions as well as AA genotype were associated with high disease activity. CC genotype of PADI4 was associated with negative RF. Finally, polymorphisms of miRNA146a and IRAK1 were a risk factor for predisposition to RA in codominant and dominant models while, polymorphisms of miRNA-499 and PADI4 were a risk factor in codominant and recessive models.

Formerly, variants of miRNA-146a rs2910164 and its target gene IRAK1 rs3027898 were proved to be associated with susceptibility to RA [20,21]. For miRNA-146a rs2910164, 
similar recent study found a significant association between miRNA-146a genotype GG and the increase risk of RA in Chinese female patients [20]. It was evidenced that estrogen could regulates miRNA-146a expression in immune cells, and miRNA-146a plays an important role in estrogen-mediated immune regulation [22]. While in contrast, other two studies observed no significant differences in miRNA-146a genotype distribution in Chinese female RA patients compared to male RA patients [23] and in Egyptian female patients compared to controls [24]. Moreover, the later study of Egyptian female RA patients reported no significant differences in all disease severity and activity parameters among different miRNA-146a genotype [24]. Studies specified that miRNA-146a is a critical manager in RA evolution as it can drive a negative feedback mechanism to prevent excess inflammation $[25,26]$. The expression of miRNA-146a was believed to be increased in RA but it is unable to properly function, leading to prolonged TNF- $\alpha$ production [27]. The elevated expression of miRNA146a might be due to the polymorphism of miRNA-146a rs2910164. This polymorphism involves a $\mathrm{G}>\mathrm{C}$ nucleotide replacement that causes change from a C: $\mathrm{U}$ pair to a $\mathrm{G}$ : $\mathrm{U}$ mismatch in the stem structure of the miRNA-146a precursor, which affects the specificity of mature miRNA-146a in binding to its targets $[6,28]$.

Our results of IRAK1 rs3027898 were in agreement with numerous previous studies in different population. Significant difference in the IRAK1 rs3027898 A>C polymorphism distribution was reported between RA patients and controls in Greece [29]. AA genotype was associated with a significantly increased risk of RA in a Chinese population [30]. IRAK1 rs3027898 was marginally associated with RA susceptibility among Koreans in an allelic model [28]. However, in disagreement with present discoveries, IRAK1 rs3027898 $\mathrm{C}$ allele was reported to be associated with an increased risk of RA in China [31]. An association between inflammatory arthritis and rs3027898 CC genotype was revealed in Song et al. meta-analysis [32]. Finally, a study on Iranian female patient observed no association between the IRAK1 rs3027898 AA genotype and the risk of RA, and concluded that the CA genotype and the A allele were not a risk factor for predisposing women to RA [33]. IRAK1 is one of the serine/threonine protein kinases which play a significant role in Toll interleukin receptor (TIR) activation of NF- $\kappa \mathrm{B}$. Upon stimulation by TIR-specific ligands, IRAK1 is autophosphorylated at multiple residues to dissociate from a TIR complex, and subsequently activates the transcription factor NF- $\kappa B$ [34]. Activated NF- $\kappa B$ increases the expression of proinflammatory cytokines such as IL-6, tissue destructive matrix metalloproteinases, TNF- $\alpha$, IL-8 and chemokines $[35,36]$. TNF- $\alpha$ and IL-1 $\beta$ were reported to target miRNA-146a

Table 5. Associations of miRNA-146a rs2910164 C/G, IRAK1 rs3027898 C/A, miRNA-499 rs3746444 T/C and PADI4 rs1748033 T/C gene polymorphisms with RA clinicopathological variables. Quantitative data were presented as mean $\pm \mathrm{SD}$; qualitative data were presented as number and percent $\mathrm{n}(\%)$. ESR: erythrocyte sedimentation rate, ANA: anti nuclear antibody; DAS28: disease activity score; RF: rheumatoid factor,

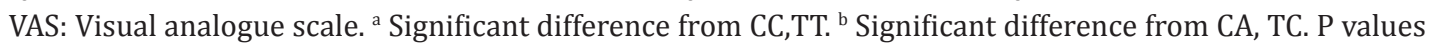
less than 0.05 are statistically significant

\begin{tabular}{|c|c|c|c|c|c|c|c|c|c|c|c|c|c|c|c|c|}
\hline \multirow[b]{2}{*}{ Genotypes } & \multicolumn{3}{|c|}{ miRNA-146a rs2910164 } & \multicolumn{5}{|c|}{ IRAK1 rs3027898 } & \multicolumn{3}{|c|}{ miRNA-499 rs 3746444} & \multicolumn{5}{|c|}{ PADI4 rs 1748033} \\
\hline & $\mathrm{cc}$ & CG & GG & $\begin{array}{c}\text { P. } \\
\text { value }\end{array}$ & cc & $\mathrm{CA}$ & AA & P-value & TT & $\mathrm{TC}$ & $\mathrm{cc}$ & $\begin{array}{c}\text { P. } \\
\text { value }\end{array}$ & TT & $\mathrm{TC}$ & $\mathrm{cc}$ & $\begin{array}{c}\text { P. } \\
\text { value }\end{array}$ \\
\hline $\mathrm{n}$ & 26 & 56 & 22 & & 42 & 40 & 22 & & 26 & 46 & 32 & & 70 & 2 & 32 & \\
\hline Age (years) & $43.3 \pm 9.5$ & $37.3 \pm 118$ & $40.8 \pm 7.8$ & 0.05 & $37.5 \pm 106$ & $40 \pm 10$ & $42.5 \pm 12.1$ & 0.25 & $36.23 \pm 10$ & $39.7 \pm 12$ & $41.9 \pm 6.9$ & 0.138 & $39 \pm 10.2$ & $19 \pm 0^{2}$ & $41,7 \pm 10.9^{\mathrm{b}}$ & 0.03 \\
\hline $\begin{array}{l}\text { Disease duration, (years) } \\
\text { Disease activity } \\
\text {-ESR ( } \mathrm{mm} / \mathrm{hr} \text { ) } \\
\text {-ANA }\end{array}$ & $\begin{array}{c}4.7 \pm 3.8 \\
41.3 \pm 25.2\end{array}$ & $\begin{array}{r}8.2 \pm 5.7= \\
42.6 \pm 23.6\end{array}$ & $\begin{array}{c}6 \pm 3.5= \\
40.2 \pm 23\end{array}$ & $\begin{array}{l}0.02 \\
0.76\end{array}$ & $\begin{array}{l}7.9 \pm 4.1 \\
37 \pm 17.4\end{array}$ & $\begin{array}{l}5.7 \pm 4.3 \\
39 \pm 21.6\end{array}$ & $\begin{array}{c}7.5 \pm 7.3^{b} \\
56 \pm 32\end{array}$ & $\begin{array}{c}0.04 \\
0.132\end{array}$ & $\begin{array}{r}7.41 \pm 5.91 \\
41.15 \pm 194\end{array}$ & $\begin{array}{r}6.32 \pm 5.3 \\
41.17 \pm 22\end{array}$ & $\begin{array}{c}7.6 \pm 3.6 \\
43.19 \pm 178\end{array}$ & $\begin{array}{l}0.23 \\
0.416\end{array}$ & $\begin{array}{l}6.9 \pm 5.2 \\
40.3 \pm 22\end{array}$ & $\begin{array}{c}11 \pm 0 \\
9 \pm 0^{\mathrm{a}}\end{array}$ & $\begin{array}{c}7 \pm 4.9 \\
47 \pm 26.2 \mathrm{~b}\end{array}$ & $\begin{array}{l}0.3 \\
0.05\end{array}$ \\
\hline $\begin{array}{l}\mathrm{ANA}^{*} \\
\mathrm{ANA} \mathrm{A}^{-}\end{array}$ & $\begin{array}{c}2(7.7) \\
24(92.3)\end{array}$ & $\begin{array}{r}8(16) \\
42(84)\end{array}$ & $\begin{array}{r}4(18.2) \\
18(81.8)\end{array}$ & 0.51 & $\begin{array}{r}6(15) \\
34(85)\end{array}$ & $\begin{array}{l}4(10.5) \\
34(89.5)\end{array}$ & $\begin{array}{l}4(20) \\
16(80)\end{array}$ & 0.61 & $\begin{array}{l}8(33.3) \\
16(66.7)\end{array}$ & $\begin{array}{l}6(14.3) \\
36(85.7)\end{array}$ & $\begin{array}{r}0(0)^{3, \mathrm{bb}} \\
32(100)\end{array}$ & 0.002 & $\begin{array}{r}4(6.3) \\
60(93.8)\end{array}$ & $\begin{array}{c}2(100) \\
0(0)\end{array}$ & $\begin{array}{c}8(25)^{a, b} \\
24(75)\end{array}$ & 0.001 \\
\hline -DAS 28 & & & & & & & & & & & & & & & & \\
\hline $\begin{array}{l}\text { Low disease activity }(\leq 3.2) \text {, } \\
\text { Moderate to high disease activity } \\
(>3.2), \\
\text { Disease severity } \\
\text {-Erosions }\end{array}$ & $\begin{array}{l}16(61.5) \\
10(38.5)\end{array}$ & $\begin{array}{l}28(50) \\
28(50)\end{array}$ & $\begin{array}{l}12(54.5) \\
10(45.5)\end{array}$ & 0.62 & $\begin{array}{l}20(47.6) \\
22(52.4)\end{array}$ & $\begin{array}{l}28(70) \\
12(30)^{2}\end{array}$ & $\begin{array}{c}8(36.4) \\
14(63.3)^{\mathrm{b}}\end{array}$ & 0.02 & $\begin{array}{l}14(53.8) \\
12(46.2)\end{array}$ & $\begin{array}{l}26(56.5) \\
20(43.5)\end{array}$ & $\begin{array}{l}16(50) \\
16(50)\end{array}$ & 0.85 & $\begin{array}{l}40(57.1) \\
30(42.9)\end{array}$ & $\begin{array}{c}2(100) \\
0(0)\end{array}$ & $\begin{array}{l}14(43.8) \\
18(56.3)\end{array}$ & 0.18 \\
\hline $\begin{array}{l}\text { Erosions } \\
\text { Erosions- }\end{array}$ & $\begin{array}{c}2(7.7) \\
24(92.3)\end{array}$ & $\begin{array}{l}14(25)^{a} \\
42(75)^{2}\end{array}$ & $\begin{array}{l}8(36.4)^{2} \\
14(63.3)\end{array}$ & 0.05 & $\begin{array}{c}16(38.1) \\
26(61.9)\end{array}$ & $\begin{array}{l}4(10)^{2} \\
36(90)\end{array}$ & $\begin{array}{c}4(18.2) \\
18(81.8)\end{array}$ & 0.009 & $\begin{array}{c}6(23.1) \\
20(76.9)\end{array}$ & $\begin{array}{c}8(17.4) \\
38(82.6)\end{array}$ & $\begin{array}{l}10(31.3) \\
22(68.8)\end{array}$ & 0.36 & $\begin{array}{l}14(20) \\
56(70)\end{array}$ & $\begin{array}{c}2(100)^{2} \\
0(0)\end{array}$ & $\begin{array}{l}8(25) \\
24(75)\end{array}$ & 0.02 \\
\hline$-\mathrm{RF}$ & & & & & & & & & & & & & & & & \\
\hline $\mathrm{RF}^{+}$, & $22(84.6)$ & $38(67.9)$ & $16(72.7)$ & 0.281 & $30(71.4)$ & $32(80)$ & $14(63.6)$ & 0.36 & $18(69.2)$ & $30(65.2)$ & $28(87.4)^{\mathrm{b}}$ & 0.081 & $56(80)$ & $2(100)$ & $18(56.25)^{a}$ & 0.02 \\
\hline $\mathrm{RF}$; & $4(15.4)$ & $18(32.1)$ & $6(27.3)$ & & 12(28.6) & $8(20)$ & $8(36.6)$ & & $8(30.8)$ & $16(34.8)$ & $4(12.5)$ & & 14(20) & $0(0)$ & $14(43.8)$ & \\
\hline -VAS $(m m)$ & $4.85 \pm 3.41$ & $5.71 \pm 3.5$ & $5.3 \pm 3.29$ & 0.54 & $5.14 \pm 3.2$ & $5.05 \pm 3.2$ & $6.18 \pm 3.54$ & 0.327 & $4.54 \pm 3.33$ & $5.35 \pm 3.4$ & $5.94 \pm 2.95$ & 0.168 & $5.2 \pm 3.3$ & $2 \pm 0$ & $5.81 \pm 3.1$ & 0.23 \\
\hline
\end{tabular}


expression [11]. Then miRNA-146a targets the expression of the following genes; IRAK1, TRAF6, IRF5, STAT1 and consequently acts as a negative regulator in Toll-like receptors (TLRs) and INF- $\alpha$ signaling pathways [24, 37].

Another polymorphisms rs3746444 of miRNA-499 and its target gene PADI4 were also reported to be involved in RA risk [22, 38]. MiRNA-499 gene polymorphisms were investigated to be associated with ADs, however, the results are still debated. The homozygous genotype $\mathrm{CC}$ and allele $\mathrm{C}$ were found to be risk factors for predisposition to RA in Iranians [39]. The miRNA-499 polymorphism was discovered to be an independent factor of RA and was associated with RA risk, severity, and activity in Egyptian female patients [23]. Our overall results were compatible with these two studies. However, no significant difference in miRNA-499 SNPs was found between RA patients and healthy controls and the miRNA-499 SNP association with anti-CCP antibody production was firstly investigated in a Han Chinese population [22]. Similarly, other study showed that miRNA-499 SNPs were not significantly associated with the risk for RA in Chinese people [30]. Therefore, a metaanalysis concluded that, miRNA-499 SNPs may be associated with susceptibility to RA in Mediterranean populations, but not in East Asians [40].

Present PADI4 results were concordant with previous report that determined an increased risk of RA in Indian population possessing rs1748033 C allele. The report also ascertained an association between anti-CCP antibody levels with high DAS28 values in RA patients [41]. Similarly, earlier studies suggested that the anti-CCP antibodies and the susceptible haplotype of PADI4 serve as markers for susceptibility and severity of the disease $[42,43]$. Likewise, inconsistent results have produced from the association studies between PADI4 SNPs and RA in different populations. PADI4 rs1748033 SNP was found to be associated with RA in Korean [44], Japanese population [38, 45], and Chinese Han population [46], while this variant was not associated with RA in UK Caucasian population [47], German [48] and Spanish population [49]. PADI4 rs1748033 SNP has been shown to be associated with greater risk of RA in men than in women and in ever-smokers than in never-smokers [50].

PADI4 gene is a vital target of miRNA-499 as it encodes PADI4 enzyme, which produces the citrullinated peptides identified by anti-CCP [51] through post-translational alteration of arginine residues to citrullines [52]. The role played by the citrullination in a number of proteins, is not known, but it has been related to some apoptosis function [53]. From the immunological view, it can be stated that post-translationally changed self-antigens are more likely to break tolerance towards self. Anti-CCP antibody can early diagnose and predict joint damage in RA [54]. In this way miRNA-499 can control the production of antiCCP antibody by controlling PADI4 gene expression. SNP rs3746444 is located at the premiRNA regions of miRNA-499 and may influence both the binding of target miRNAs to $3 p$ mature miRNAs and premiRNA maturation of $5 p$ and $3 p$ miRNAs. Researchers observed that RA patients with miRNA-499 CT genotype had a higher level of anti-CCP antibody more than homozygote $[22,23]$.

In spite of the considerable efforts to explore the possible relationship between the 4 SNPs and RA risk, some limitations should be considered. First, as this is a hospital-based, case-control study, selection bias is unavoidable, and the subjects are not fully representative of the general population. Second, we have no data regarding anti-CCP antibodies; HLA-DRB1 shared epitope and smoking history. Thus, we could not determine the association between these 4 SNPs and these factors; however, this is the first study that addresses association of IRAK1 rs3027898 and PADI4 rs1748033 with susceptibility of RA in Egyptians. Third, we are aware that a single case-control study may not be sufficient to fully interpret the relationship between them and susceptibility for RA in Egypt because of the relatively small number of patients involved. Nevertheless, we believe that the results of this study provide an important input into the debate concerning the clinical relevance of studied variant.

In conclusion, our study provides strong evidence that miRNA-146a rs2910164, miRNA-499 rs3746444, IRAK1 rs3027898 and PADI4 rs1748033 polymorphisms may 
Shaker et al.: MiRNA-146a, miRNA-499, IRAK1 and PADI4 Polymorphisms In Rheumatoid Arthritis

contribute to the risk of RA in Egyptian population. However, further studies in other ethnic groups and with larger sample sizes are required to confirm our findings. Consistent with growing evidence, the present study has demonstrated that miRNA polymorphisms may be suitable for use as diagnostic biomarkers for RA in future. Nevertheless, by identifying new genetic predisposing factors to immune diseases, even though overlapping, we highlight new pathways in disease susceptibility and possibly in its therapeutic intervention.

\section{Acknowledgements}

The authors thank the participating RA patients and all subjects for participating in the study.

\section{Disclosure Statement}

No conflict of interests exists.

\section{References}

1 Davis JM, Matteson EL: My treatment approach to rheumatoid arthritis. Mayo Clinic Proc 2012;87:659673.

2 Oliver JE, Silman AJ: Why are women predisposed to autoimmune rheumatic diseases? Arthritis Res Ther 2009;11:252.

-3 Deighton CM, Walker DJ, Griffiths ID, Roberts DF: The contribution of HLA to rheumatoid arthritis. Clin Genet 1989;36:178-182.

4 Barton A, Worthington J: Genetic susceptibility to rheumatoid arthritis: an emerging picture. Arthritis Rheum 2009;61:1441-1446.

5 Nakasa T, Shibuya H, Nagata Y, Niimoto T, Ochi M: The inhibitory effect of microRNA-146a expression on bone destruction in collagen-induced arthritis. Arthritis Rheum 2011;63:1582-1590.

6 Chatzikyriakidou A, Voulgari PV, Georgiou I, Drosos AA: miRNAs and related polymorphisms in rheumatoid arthritis susceptibility. Autoimmun Rev 2012;11:639-641.

7 Zwiers A, Kraal L, van de PouwKraan TC, Wurdinger T, BoumaG, Kraal G: A variant of the IL-23R gene associated with inflammatory bowel disease induces loss of microRNA regulation and enhanced protein production. J Immunol 2012;188:1573-1577.

8 Murata K, Yoshitomi H, Tanida S, Ishikawa M, Nishitani K, Ito H, Nakamura T: Plasma and synovial fluid microRNAs as potential biomarkers of rheumatoid arthritis and osteoarthritis. Arthritis Res Ther 2010;12:R86.

Z9 Zamore PD, Haley B: Ribo-genome: the big world of small RNAs. Science 2005;309: 1519-1524.

10 Gabay O, Sanchez C: Epigenetics, sirtuins and osteoarthritis. Joint Bone Spine 2012;79:570-573.

11 Apparailly F: Looking for microRNA polymorphisms as new rheumatoid arthritis risk loci? Joint Bone Spine 2010;77:377-379.

12 Zhao ZZ, Croft L, Nyholt DR, Chapman B, Treloar SA, Hull ML, Montgomery GW: Evaluation of polymorphisms in predicted target sites for micro RNAs differentially expressed in endometriosis. Mol Hum Reprod 2011;17:92-103.

13 Nakasa T, Miyaki S, Okubo A, Hashimoto M, Nishida K, Ochi M, Asahara H: Expression of microRNA-146a in rheumatoid arthritis synovial tissue. Arthritis Rheum 2008;58:1284-1292.

14 Duroux-Richard I, Presumey J, Courties G, Gay S, Gordeladze J, Jorgensen C, Kyburz D, Apparailly F: MicroRNAs as new player in rheumatoid arthritis. Joint Bone Spine 2011;78:17-22.

15 Ying B, Shi Y, Pan X, Song X, Huang Z, Niu Q Cai B, Wang L: Association of polymorphisms in the human IL10 and IL-18 genes with rheumatoid arthritis. Mol Biol Rep 2011;38:379-385.

16 Yuan FL, Hu W, Lu WG, Li X, Li JP, Xu RS, Li CW, Chen FH, Jin C: Targeting interleukin-21 in rheumatoid arthritis. Mol Biol Rep 2011;38:1717-1721. 

Arthritis

17 Huang CH, Cong L, Xie J, Qiao B, Lo SH, Zheng T: Rheumatoid arthritis associated gene-gene interaction network for rheumatoid arthritis candidate genes. BMC Proc 2009;15:S75

-18 Arnett FC, Edworthy SM, Bloch DA, McShane DJ, Fries JF, Cooper NS, Healey LA, Kaplan SR, Liang MH, Luthra HS: The American Rheumatism Association1987 revised criteria for the classification of RA. Arthritis Rheum 1998;31:315-324.

19 http://www.blast.ncbi.nlm.nih.gov/Blast.cgi

20 Zhou X, Zhu J, Zhang H, Zhou G, Huang Y, Liu R: Is the microRNA-146a (rs2910164) polymorphism associated with rheumatoid arthritis? Association of microRNA-146a (rs2910164) polymorphism and rheumatoid arthritis could depend on gender. Joint Bone Spine 2015;82:166-171.

21 Han TU, Cho SK, Kim T, Joo YB, Bae SC, Kang C: Association of an activity-enhancing variant of IRAK1 and an MECP2-IRAK1 haplotype with increased susceptibility to rheumatoid arthritis. Arthritis Rheum 2013;65:590-598.

22 Dai R, Phillips RA, Zhang Y, Khan D, Crasta O, Ahmed SA: Suppression of LPS-induced Interferon-gamma and nitric oxide in splenic lymphocytes by select estrogen-regulated microRNAs: a novel mechanism of immune modulation. Blood 2008;112:4591-4597.

-23 Yang B, Zhang JL, Shi YY, Li DD, Chen J, Huang ZC: Association study of single nucleotide polymorphisms in pre-miRNA and rheumatoid arthritis in a Han Chinese population. Mol Biol Rep 2011;38:4913-4919.

24 El-Shal AS, Aly NM, Galil SM, Moustafa MA, Kandel WA: Association of microRNAs genes polymorphisms with rheumatoid arthritis in Egyptian female patients. Joint Bone Spine 2013;80:626-631.

-25 Taganov KD, Boldin MP, Chang KJ, Baltimore D: NF-kappa B-dependent induction of microRNA miR146a, an inhibitor targeted to signaling proteins of innate immune responses. Proc Natl Acad Sci USA 2006;103:12481-12486.

-26 Zilahi E, Tarr T, Papp G, Griger Z, Sipka S, Zeher M: Increased microRNA-146a TRAF6 gene and decreased IRAK1 gene expressions in the peripheral mononuclear cells of patients with Sjögren's syndrome. Immunol Lett 2011;141:165-168.

27 Pauley K, Satoh M, Chan A, Bubb MR, Reeves WH, Chan EK: Upregulated miR-146a expression in peripheral blood mononuclear cells from rheumatoid arthritis patients. Arthritis Res Ther 2008;10:R101.

28 Yue C, Wang M, Ding B, Wang W, Fu S, Zhou D: Polymorphism of the pre-461 miR-146a is associated with risk of cervical cancer in a Chinese population. Gynecol Oncol 2011;122:33-37.

29 Chatzikyriakidou A, Voulgari PV, Georgiou I, Drosos AA: A polymorphism in the 3'-UTR of interleukin-1 receptor-associated kinase (IRAK1), a target gene of miR-146a, is associated with rheumatoid arthritis susceptibility. Joint Bone Spine 2010;77:411-413.

30 Zhang H, Pu J, Wang X, Shen L, Zhao G, Zhuang C and Liu R: IRAK1 rs3027898 C/A polymorphism is associated with risk of RA. Rheumatol Int 2013;33:369-375.

-31 Yang XK, Li P, Zhang C, Leng RX, Li S, Liu J, Li BZ, Pan HF, Ye DQ: Association between IRAK1 rs3027898 and miRNA-499 rs3746444 polymorphisms and rheumatoid arthritis: A case control study and meta-analysis. Z Rheumatol 2017;76:622-629. DOI 10.1007/s00393-016-0169-0

-32 Song GG, Bae SC, Seo YH, Kim JH, Choi SJ, Ji JD, Lee YH: The association between susceptibility to inflammatory arthritis and miR-146a, miR-499 and IRAK1 polymorphisms. A meta-analysis. Z Rheumatol 2015;74:637- 645 .

-33 Atabaki M, Hashemi M, Daneshvar H, Alijani E: Association between interleukin-1 receptor associated kinase 1 rs3027898 A/C gene polymorphism and rheumatoid arthritis. Biomed Rep 2017;6:335-338.

34 Akira S, Takeda K: Toll-like receptor signaling. Nat Rev Immunol 2004;4:499-511.

35 Dunne A, O’Neill LA: The interleukin-1 receptor/Toll-like receptor superfamily: signal transduction during inflammation and host defense. Sci STKE 2003;2003:Re 3.

-36 Pierer M, Rethage J, Seibl R, Lauener R, Brentano F, Wagner U: Chemokine secretion of rheumatoid arthritis synovial fibroblasts stimulated by Toll-like receptor 2 ligands. J Immunol 2004;172:1256-1265.

37 Tang Y, Luo X, Cui H,Guo Y, Huang X, Zhou H, de Vries N, Tak PP, Chen S, Shen N: MicroRNA-146a contributes to abnormal activation of the type I interferon pathway in human lupus by targeting the key signaling proteins. Arthritis Rheum 2009;60:1065-1075.

38 Suzuki A, Yamada R, Chang X, Tokuhiro S, Sawada T, Suzuki M, Nagasaki, M, Nakayama-Hamada, M, Kawaida, R, Ono M: Functional haplotypes of PADI4, encoding citrullinating enzyme peptidyl arginine deiminase 4, are associated with rheumatoid arthritis. Nat Genet 2003;34:395-402. 


\section{Cellular Physiology Cell Physiol Biochem 2018;46:2239-2249 \begin{tabular}{l|l} 
DOI: 10.1159/000489592 & क 2018 The Author(s). Published by S. Karger AG, Basel \\
www.karger.com/cpb
\end{tabular}}

and Biochemistry Arthritis

-39 Hashemi M, Eskandari-Nasab E, Zakeri Z, Atabaki M, Bahari G, Jahantigh M, Taheri M, Ghavami: Association of pre-miRNA-146a rs2910164 and pre-miRNA-499rs3746444 polymorphisms and susceptibility to rheumatoid arthritis. Mol Med Rep 2013;7:287-291.

-40 Lu L, Tu Y, Liu L, Qi J, He L: MicroRNA-499 rs3746444 polymorphism and autoimmune diseases risk: a meta-analysis. Mol Diagn Ther 2003;18:237-242.

41 Panati K, Pal S, Rao KV, Reddy VD: Association of single nucleotide polymorphisms (SNPs) of PADI4 gene with rheumatoid arthritis (RA) in Indian population. Genes Genet Syst 2012;87:191-196.

42 Bas S, Genevay S, Meyer O, Gabay C: Anti-cyclic citrullinated peptide antibodies, IgM and IgA rheumatoid factors in the diagnosis and prognosis of rheumatoid arthritis. Rheumatology (Oxford) 2003;42:677-680.

43 Meyer, O, Labarre, C, Dougados, M, Goupille P, Cantagrel A, Dubois, A, Nicaise-Roland P, Sibilia J, Combe B: Anticitrullinated protein/peptide antibody assays in early rheumatoid arthritis for predicting five year radiographic damage. Ann Rheum Dis 2003;62:120-126.

44 Kang CP, Lee HS, Ju H, Cho H, Kang C, Bae SC: A functional haplotype of the PADI4 gene associated with increased rheumatoid arthritis susceptibility in Koreans. Arthritis Rheum 2006;54:90-96.

45 Iwamoto T, Ikari K, Nakamura T, Kuwahara M, Toyama Y, Tomatsu T: Association between PADI4 and rheumatoid arthritis: a meta-analysis. Rheumatology (Oxford) 2006;245:804-807.

46 Du Y, Liu X, GuoJP, Liu X, Li R, Zhao Y: Association between PADI4 gene polymorphisms and anti-cyclic citrullinated peptide antibody positive rheumatoid arthritis in a large Chinese Han cohort. Clin Exp Rheumatol 2014;32:377-382.

47 Barton A, Bowes J, Eyre S, Spreckley K, Hinks A, John S: A functional haplotype of the PADI4 gene associated with rheumatoid arthritis in a Japanese population is not associated in a United Kingdom population. Arthritis Rheum 2004;50:1117-1121.

-48 Hoppe B, Haupl T, Gruber R, Kiesewetter H, Burmester GR, Salama A: Detailed analysis of the variability of peptidyl arginine deiminase type 4 in German patients with rheumatoid arthritis: a case-control study. Arthritis Res Ther 2006;8:R34.

49 Martinez A, Valdivia A, Pascual-Salcedo D, Lamas JR, Fernandez-Arquero M, Balsa A: PADI4 polymorphisms are not associated with rheumatoid arthritis in the Spanish population. Rheumatology (Oxford) 2005;44:1263-266.

50 Kochi Y, Thabet MM, Suzuki A, Okada Y, Daha NA, Toes RE: PADI4 polymorphism predisposes male smokers to rheumatoid arthritis. Ann Rheum Dis 2011;70:512-515.

51 Schellekens GA, Visser H, de Jong BA: The diagnostic properties of rheumatoid arthritis antibodies recognizing a cyclic citrullinated peptide. Arthritis Rheum 2000;43:155-163.

52 Chavanas S, Mechin MC, Takahara H. Comparative analysis of the mouse and human peptidyl arginine deiminase gene clusters reveals highly conserved non-coding segments and a new human gene PADI6. Gene 2004;330:19-27.

53 Asaga H, Yamada M, Senshu T: Selective deimination of vimentin in calcium ionophore-induced apoptosis of mouse peritoneal macrophages. Biochem Biophys Res Commun 1998;243:641-646.

54 Nieword TB, Harrison MJ, Paget SA: Anti-CCP antibody testing as a diaganostic and prognostic tool in rheumatoid arthritis. Q J Med 2007;100:193-201. 